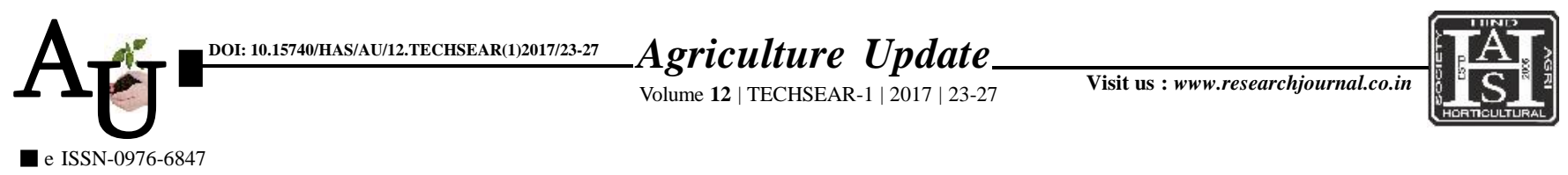

\title{
Research Article: Free ranging desi poultry as a component in sugarcane integrated farming system and its effect on growth and productivity of sugarcane
}

\section{T. ANANTHI AND M. MOHAMED AMANULLAH}

Article Chronicle:

Received :

05.07.2017;

Accepted :

22.07.2017

KeY WoRds:

Sugarcane, Desi

poultry, Weed

density, Growth, Yield
SUMMARY : A field experiment was conducted in farmers field at Coimbatore during Kharif, 2016 -17 to study the effect of introducing free ranging desi poultry in maize integrated farming system and its on growth and yield of maize. The popular variety Mandya was used as test variety. Two farming systems viz., Sugarcane alone; Sugarcane + desi poultry ( 2 hens and 1 rooster for 3 cents) were evaluated under field conditions. The sugarcane + desi poultry recorded better growth parameters, yield attributes and yield than under sole sugarcane. Sugarcane along with desi poultry lowered the weed density and dry weight during critical stage of the crop growth. The increase in yield under sugarcane + desi poultry was negligible when compared to cane yield of sugarcane. The yield attributes viz., cane length $(\mathrm{cm})$, cane girth $(\mathrm{cm})$, number of millable canes, number of inter nodes, individual cane weight and cane yield were slightly higher under sugarcane + desi poultry farming systems. The treatment combination of sugarcane with desi poultry recorded higher available soil nutrients (NPK) than sole sugarcane.

How to cite this article : Ananthi, T. and Amanullah, M. Mohamed (2017). Free ranging desi poultry as a component in sugarcane integrated farming system and its effect on growth and productivity of sugarcane. Agric. Update, 12(TECHSEAR-1) : 23-27; DOI: 10.15740/HAS/AU/12.TECHSEAR(1)2017/23-27.
Author for correspondence :

\section{MOHAMED}

AMANULLAH

Department of

Agronomy, Tamil Nadu Agricultural University, COIMBATORE (T.N.) INDIA Email:ananthu12@gmail. com

See end of the article for authors' affiliations 